\title{
The Post-Imperial Relationship with the Royal Navy: On the Beach?
}

\section{Stephen Prince}

Fondamentalement, l'Empire britannique s'était basée sur la puissance maritime et sur la domination de la Marine royale britannique. Cependant, les réalités du vingtième siècle étaient telles que la marine royale avait besoin de renforcement et cela a pris la forme d'" unité de flotte ", clones nationaux de la marine royale travaillant au sein d'une structure impériale. Ce concept a été extrêmement efficace et a atteint sa maturité au cours de la seconde guerre mondiale avec des résultats stratégiques significatifs. Néanmoins, et en même temps, les marines et les nations nouvelles étaient en train d'atteindre leur pleine maturité et les relations ont transité du paternel au fraternel. Événements autour de la guerre de Corée ont alors provoqué une autre transition où les nations et les marines ont poursuivi des objectifs de sécurité connexes, mais diversifiés. Bien que les associations sont devenues bien plus souple, le modèle de travail en commun employé par le Commonwealth dans un but de compréhension et de coopération a été largement suivi, aidant la Grande-Bretagne à intégrer des alliés nouveaux tout en fonctionnant avec des partenaires de plus long terme.

The phrase "on the beach" suggests a variety of meanings, none of them particularly dynamic or positive. It may envisage jetsam, a grounding or retirement. It is particularly the last meaning that many historians and defence commentators, particularly British ones, have tended towards when considering the post-1945 defence and security links between the members of the Empire and Commonwealth. A new variation on the phrase though emerged a decade after the Second World War when On the Beach (1957) became an influential bestseller for Nevil Shute, and would be filmed in Australia two years later. Nevil Shute Norway was a British aeronautical engineer and writer who had served in the Royal Navy Volunteer Reserve (RNVR) in the Second World War before immigrating to Australia. The book is dominated by the shadow of superpower atomic warfare, as well as nuclear proliferation, and is populated by a mix of Australian, American and British characters. When it was filmed in 1959 the 'starring' ships were the carrier HMAS Melbourne, built in Britain for the Royal Navy (RN) and then purchased for the Royal Australian Navy (RAN) in 1949, and the submarine HMS Andrew. In the film Andrew plays the USS Sawfish, a further twist for

The Northern Mariner/Le marin du nord XXIV, Nos. 3 \& 4 (Jul. \& Oct. 2014), 296-310 Canadian Military History 23, Nos. 3 \& 4 (Summer \& Autumn 2014), 296-310 
an RN ship on loan to the RAN. In a small way these complexities illustrate the much more nuanced reality of Commonwealth defence and naval relations, particularly after 1945 - relations that have continually transformed but which still have relevance to the interdependences of today. Many other papers in this volume also illustrate this theme but this chapter will examine the phenomenon as national interaction and from the British perspective, where the story is often seen as marginal or ignored. In particular it will also examine the significant turning points in the nature of co-operation between 1945-56.

\section{Imperial Defence Before 1945}

The growth of Britain's Empire involved many colonial campaigns ashore, usually with direct participation by Royal Navy personnel. ${ }^{1}$ However, it was much more fundamentally enabled and then protected by the Royal Navy's dominance afloat. The security this provided permitted the 'world wide web' of sea-delivered trade to function effectively, ensuring Britain's prosperity, and the opportunity for the Empire, and particularly the Dominions, to develop largely safe from external threats. For much of the nineteenth century this system was both remarkably effective and costeffective. ${ }^{2}$ However, by the 1890 s, Britain faced the rise of peer competitors, such as America, and a direct challenge in the form of Imperial Germany's naval expansion. Facing the German threat in home waters resulted in fundamental amendments to British policy, particularly the ententes which rapidly became de facto alliances with France and Russia. In imperial and naval policy the ententes were accompanied by the concentration of the RN on home bases, denuding the distant stations. For Admiral Sir John Fisher this was the point at which to propose the 'fleet unit', which, in James Goldrick's excellent description, was a form of cloning of a naval service which has had an impact through to today in more than twenty Commonwealth navies. ${ }^{3}$ This swept aside the few local naval services which had developed, and allowed the Dominions which chose to adopt it to make a qualitative leap that would have been impossible independently. The Royal Navy provided expertise and viable career structures for the Dominions, thus economies of scale, both naval and industrial to Great Britain.

The new system of fleet units (but also of Royal Navy ships subsidised by Dominions and colonies in preference to a naval force) was soon 'stress tested' in the

1 See Peter Hore (ed.), Seapower Ashore (London: Chatham Publishing, 2001).

2 Andrew Lambert, "The Shield of Empire 1815-1895" in J. R. Hill (ed.) The Oxford Illustrated History of the Royal Navy (Oxford: Oxford University Press, 1995) and Andrew Lambert, "The Royal Navy and imperial defence, 1856-1918" in Greg Kennedy (ed.), Imperial Defence, The old world order 1856-1956 (Routledge; London, 2008).

3 See James Goldrick in this volume but also Nicholas Lambert, "Economy or Empire? The fleet unit concept and the quest for collective security in the Pacific 1909-1914" in Keith Neilson and Greg Kennedy (eds), Far Flung Lines: Studies in Imperial Defence in Honour of Donald Mackenzie Schurman (London: Frank Cass, 1997). 
First World War and found to be remarkably effective. ${ }^{4}$ Though the lack of decisive fleet actions disappointed some observers, the world's oceans remained very largely accessible to Britain, her allies and the merchant fleets. In addition, there was a great deal of activity that went on beyond the Euro-centric war, much of it maritime. Dominion forces were central to this and they contained the conflict and frustrated the desire of both Germany and local interests, to spread the fighting or take advantage of the diversion of Britain's major forces to Europe. ${ }^{5}$ The overall impact of Imperial seapower was fundamental. Germany was isolated from the world economy and confined to central Europe. Frustration, both from Jutland and fighting in France, drove Germany to unrestricted submarine warfare, which proved challenging to counter but was an inadequate attack in isolation and brought the USA into the conflict. This allowed the naval blockade to be tightened still further and provoked Germany's failed offensives of 1918. In those attacks the German ground forces were fatally distorted by the impact of the blockade, in particular lacking the horses and motor transport required to turn advances into sustained breakthrough offensives. This was a vital, if underappreciated, impact of the blockade, as significant as the more widely known impact on Germany's broader economy and society, which helped to provoke the German naval mutinies of $1918 .^{6}$ Simultaneously, imperial naval power permitted the entente powers to run unprecedentedly integrated economies, where Welsh coal and American steel sustained French industry with the finance coming from maritime trade and investments. French weapons then equipped US troops which, together with the troops of the British and French empires, provided the crucial margin of victory in $1918 .^{7}$

Post 1918 the 'cloned' pattern broadly continued, as the same mutual advantages of viability and economies of scale still endured, as did the trade links that would later be reinforced by imperial tariffs. Elements of the Admiralty were still attracted to a reversion to a single service and options for unified control but ultimately RN opinion evolved maturely and were recognised in the 1919 Memorandum on 'Imperial Naval Defence' that:

$5 . .$. It must be remembered that the Dominions are quite free to determine

$4 \quad$ For the subsidy option see Michael Wynd's paper in this volume.

5 See David Stevens's excellent forthcoming history of the Royal Australian Navy in the First World War for the best analysis of this topic.

6 On this topic see David T. Zambecki, The German Offensives of 1918: A Case Study in the Operational Level of War (London: Routledge, 2006), Stephen Prince, "The Royal Navy and the First World War" in Mungo Melvin (ed.) The First World War Battlefield Guide: The Western Front (London: British Army, 2014) and Norman Friedman, Fighting the Great War at Sea, Strategy, Tactics and Technology (London: Seaforth Publishing, 2014).

7 Keith Neilson, "Reinforcements and Supplies from Overseas: British Strategic Sealift in the First World War" in Greg Kennedy (ed.) The Merchant Marine in International Affairs, 1850-1950 (London: Frank Cass, 2000) and B.J.C McKercher, "Economic Warfare" and Hew Strachan, "Economic Mobilization: Money, Munitions and Machines" both in Hew Strachan (ed.), The Oxford Illustrated History of the First World War (Oxford: Oxford University Press, 1998). 
the extent and nature of their contribution, and are naturally jealous of their constitutional rights....

$6 \ldots$... It now seems to be clear that co-operation on the model of the Australian Navy is likely to be the most satisfactory system in these respects, and the greater financial obligations are likely to be undertaken when ships are maintained by the Dominions, manned by their own men and based on their own ports. ${ }^{8}$

Economy and arms limitations now focused operational capability more at the level of the cruiser and destroyer than the battlecruiser. These smaller ships were also appropriate to the multiple security risks of the period, with cruisers suiting the range requirements of the Pacific, and could initially be made available on favourable terms as war-time fleets contracted. ${ }^{9}$ The Royal Navy remained the most powerful naval force on the planet but national policy had now accepted parity with the USA and the economic basis of power was clearly diminished. Also reduced was the political appetite for risking major conflict, as opposed to colonial policing. National consciousnesses had also been significantly developed by the First World War and were closely associated with major land engagements, such as Anzac and Vimy Ridge. By contrast naval forces were still more closely associated with their Royal Navy 'parent'. While this close association raised their prestige and made viable the operational command that was largely denied to army officers it also limited their intimate connection with national life, though a significant exception was the decision of the RCN to prioritise the a volunteer reserve from 1923. ${ }^{10}$ Perhaps the most noticeable failure of Britain during this period was the very limited investment in developing any colonial naval capacity. To the extent that this was done, it stressed 'white' personnel, particularly in officers and facilities to enable the main fleets. There were no developments remotely matching those of the Indian Army and this would inhibit both the later development of the services and Britain's ability to influence them. ${ }^{11}$

The approach of the Second World War saw re-armament that generally favoured naval and air forces throughout the Commonwealth, but also saw a consensus among the governments for appeasement. Much of this was based on the weakness of

8 Memorandum, “Imperial Naval Defence', October 1919” in Nicholas Tracy (ed.), The Collective Naval Defence of the Empire, 1900-1940 (Aldershot: Ashgate for the Naval Record Society, 1997), 252.

9 David Stevens, "The RAN/RN Cruiser Exchange 1924-36" in Kathryn Young and Rhett Mitchell (eds), The Commonwealth Navies, 100 Years of Cooperation (Canberra: Sea Power Centre Australia, 2012).

10 Marc Milner, Canada's Navy, The First Century (Toronto: University of Toronto Press, 1999), 62. For a fascinating comparative study of the impact of lack of command opportunities in the Canadian Army see Douglas Delaney, Corps Commanders, Five British and Canadian Generals at War, 1939-45 (Vancouver: University of British Columbia Press, 2011).

11 James Goldrick, No Easy Answers, The Development of the Navies of India, Pakistan, Bangladesh and Sri Lanka 1945-1996 (New Delhi: Lancer Publishers, 1997), ch. 1 and C. Uday Bhaskar's paper in this volume. 
their inter-dependent economies, the assessment that any war would only encourage a vicious cycle of opportunistic threats from Germany, Italy and Japan, and a common judgement that America would remain neutral. ${ }^{12}$ When Britain and France declared war their Empires were again automatically with them, though with greater internal dissent than in 1914. As the Admiralty had recognised in 1919, twelve years before the Statue of Westminster, there was now certainly nothing automatic about Dominion decisions. Eire chose neutrality; South Africa's parliamentary vote for war was narrow; and Canada's parliament was now required to confirm war, which delayed Canada's declaration by a week. However, the almost universal move to both war and continuing intimate integration was even more remarkable given its considered and voluntary nature.

The Second World War rapidly transformed the nature of the Commonwealth naval partnership. Much of this transformation was triggered by the strategic earthquake of German success on land in 1940, which changed the nature of the conflict, giving Germany unprecedented maritime access and removing Britain's primary land ally. The conflicting French regimes of 1940-42 also increased the strategic opportunity for Japan, as it was able to encroach on French colonies, and further improve its military position without immediately causing war. Much greater naval forces were now required and they would need to undertake a diverse range of operations across the globe. Britain and the Dominions abandoned 'limited liability' forces and expanded to create 'citizen' navies that were unprecedented except in the USN in the same conflict. ${ }^{13}$ A separate Royal New Zealand Navy (RNZN) was born in 1941 and the South African Naval Forces (SANF) the following year. The RAN expansion was over 500 percent, the RN over 700 percent and the RCN over 4,200 percent. ${ }^{14}$

The results of the genuinely global nature of the conflict were incredibly diverse experiences across sea, air and land, across fleet actions, anti-submarine warfare and amphibious assaults. Just as in the First World War the blockade had been vital, but also the requirement for offensive action had also been dramatically increased. ${ }^{15}$ There was increasing exposure to the USN for some and a growing awareness that the scale of Commonwealth effort was often now underwritten by sometimes superior US technology and the scale of US economic assistance through

12 Paul Twomey, "Munich" in Carl Bridge (ed.), Munich to Vietnam, Australia's relations with Britain and the United States since the 1930s (Melbourne: Melbourne University Press, 1991).

13 Brian Lavery, Hostilities Only, Training the Wartime Royal Navy (London: Conway, 2004), 7.

14 David Stevens, "The Australian Naval Experience, 1901-2010" in this volume and Stephen Roskill, The War at Sea, Volume I, The Defensive (London: Her Majesty's Stationary Office, 1954), Appendix C, 575-576.

15 Richard Overy, Why the Allies Won (London: Jonathan Cape, 1995) and R.L. DiNardo, Mechanized Juggernaut or Military Anachronism? Horses and the German Army in World War II (New York: Greenwood Press, 1991). 
Lend-Lease. Domestic industries were also stimulated with increasing the rate of technology transfer to the Dominions. However, the overwhelming experience was of intimate co-operation in vital roles for a shared voluntary cause, where nationality was now frequently a submerged or secondary consideration. There might be no RAN ships at D-Day but there were still 1,100 RAN personnel. Lieutenant Robert Hampton Gray RCNVR, who won a posthumous Victoria Cross flying with 1841 Squadron Fleet Air Arm from HMS Formidable is equally commemorated by the RN and RCN. The RCN could move their main commemorative dinner to the Battle of the Atlantic, without having to reject Trafalgar Night, recognising their enormous contribution to ASW. ${ }^{16}$ The result was mutual regard and respect which have set the context for all subsequent interaction. British officers had proved largely competent, had coped with dramatic strategic shocks, had been key enablers of Dominion expansion and increasingly constructive when exercising multinational command. ${ }^{17}$ Dominion officers had demonstrated the maturity of themselves and their services in operational and national command. ${ }^{18}$ It was a decisive shift from paternal to fraternal relations. In Norman Friedman's words this was, "voluntary co-operation unique beyond words." 19

\section{The Decade of Post-Imperial Transition 1945-56}

The British Pacific Fleet (BPF) was a remarkable expression of Commonwealth maturity and increased interdependence, but its subordination within a USN dominated theatre also demonstrated the fundamental shift in both naval and broader strategic power by 1945. For many historians this is the turning point at which the Commonwealth nations, including Britain, shifted their priority to relations with the USA and away from an imperial legacy. ${ }^{20}$ However, the danger of this approach is that it truncates the Second World War legacy too directly to later events and trends, which were not as significant as they may seem in retrospect. Indeed one of the causes of the unity of the BPF was the reality that in the later stages of the Pacific War the US, now deploying the vast majority of forces, became less interested in integrating the forces and concerns of its Allies. Commonwealth unity now had renewed potential benefit in providing a collective seat at the American table.

Britain's priority for maintaining a close collective association arose from an early assessment of the Soviet Union as a security threat. While Britain assessed that the USA would again be the key ally in any confrontation with the Soviets there was

16 Marc Milner, Canada's Navy, 195.

17 See Michael Whitby (ed.), Commanding Canadians, The Second World War Diaries of A.F.C. Layard (Vancouver: University of British Columbia Press, 2005).

18 David Stevens (ed.), The Royal Australian Navy in World War II (Crows Nest: Allen \& Unwin, 1996).

19 Comments by Dr Friedman in discussion at the Australian Defence Force Academy, July 2011.

20 For example David French, The British Way in Warfare (London: Unwin Hyman, 1990), 205 and John Baylis, Anglo-American Defence Relations 1945-1984 (London: MacMillan, 1986), 61. 
also assessed to be potential for a conflict where the USA was not initially involved. ${ }^{21}$ This compounded the requirement to try and achieve a Commonwealth unity that Britain still aspired to lead, though there was an early acceptance that the new states of the Indian sub-continent would be unlikely to align militarily but might be encouraged to provide diplomatic and possibly basing support. ${ }^{22}$ Britain therefore explicitly envisaged its post-war strategy as a new 'Commonwealth Defence.' The stress on the Commonwealth partly arose from an assessment, which persisted even after the signing of the North Atlantic Treaty in 1949, that defending against a Soviet attack against Western Europe was not feasible. Forces on the continent were there to encourage European re-armament and to counter Soviet political pressure but would be withdrawn in the event of invasion. ${ }^{23}$ The enduring elements of defence were to be the security of the UK, the security of the sea lanes and maintaining a position in the Middle East, with the UK and the Middle East being used as bases for strategic air attacks. This strategy was intimately connected with Britain's decision to develop atomic weapons and long range missiles.

By 1950 this strategy had achieved a surprising level of consensus particularly with Australia, New Zealand and South Africa, all of whom had committed or made preparations to provide forces quickly in a future conflict, accepting that the pace of a likely war would emphasise early deployment. Moves to support this policy included New Zealand's referendum approving peace-time conscription in 1949 and the 1950 decision to withdraw the last, entirely Australian elements of the British Commonwealth Occupation Force (BCOF) from Japan to provide the capacity to train future forces. On the naval side, the Middle East commitment would include the RNZNs frigate force and probably the RAN light carrier. Field Marshal Slim described New Zealand's support as being "almost embarrassingly co-operative." 24 The underlying factors which supported this consensus included an economic alignment that actually converged still further after the war. The Cold War split the European market, and America ran enormous surpluses on foreign trade which led to a dollar shortage worldwide. In this situation intra-Commonwealth trade increased, with Australian imports from the UK rising from forty-one percent of Australia's international trade in 1938-39 to fifty percent by 1948-49. This in turn increased the integration of the UK's Sterling currency area and the value of the Sterling balances held by the Dominions,

21 Julian Lewis, Changing Direction, British Military Planning for Post-war Strategic Defence, 1942-47 (London: The Sherwood Press, 1988).

22 The loss of Indian Army manpower was Britain's greatest military concern and one of the drivers for Britain's peacetime conscription 1946-62. It was partly offset by agreements with India and Nepal that allowed Britain to continue to recruit eight battalions of Gurkhas who were prominent in the Malayan (1948-60) and Confrontation (1962-66) campaigns.

23 Paul Cornish, British Defence Planning for the Defence of Germany (London: MacMillan, 1996).

24 Ian McGibbon, New Zealand and the Korean War, Volume I, Politics and Diplomacy (Auckland: Oxford University Press, 1992), 29-31. 
which were only freely exchangeable for British goods. ${ }^{25}$ These credits with the UK combined with the availability of ships from wartime production that the UK could not man. The result was another transfer of ships, notably light carriers, to the Commonwealth on favourable terms that maintained standardisation and interoperability, as well logically promoting continued training and support links. ${ }^{26}$ It was also a fertile situation for further collaborations on technology and facility sharing such as the Anglo-Australian Joint Project, which helped develop naval weapons such as Ikara and Seaslug. ${ }^{27}$ By contrast equipment from America, which involved the expenditure of scarce US dollars, was impractical. This was reinforced by the difficulties Australia, New Zealand and South Africa had in accessing US information. This indicated the unprecedented growth in the US military, and the difficulties of then achieving large scale demobilisation while retaining world-wide responsibilities. In this situation prioritisation was inevitable and the geography of the southern dominions, combined with their already friendly status, meant they were not a priority. In 1948 this achieved a more formal status when Australian security leaks led to a suspension of any US classified material being exchanged with Australia. The underlying pattern though was that the Dominions also produced very little information of interest to the USA so that there was also little incentive to take any risk on this issue. ${ }^{28}$ While the Dominions were aware that a close Commonwealth association might inhibit the ultimate development of close defence and security relations with the USA, they also recognised the dynamics determining the US attitude. On balance collective Commonwealth association was again the best opportunity for a close connection to America. ${ }^{29}$ For Britain, the value of this was in encouraging Commonwealth cohesion and improving Britain's standing with the USA - as well as the strain it would place on cooperation if there were continuing restrictions on information. When a link to America through the Commonwealth connection - part of the 'Five Eyes' agreements of the period - was restored in 1950 the value of it was acknowledged by Prime Minister Menzies to Prime Minster Attlee. ${ }^{30}$

25 David Lee, The Search for Security, The Political Economy of Australia's Postwar Foreign and Defence Policy (Canberra, Allen \& Unwin, 1995), 71. British exports from the Commonwealth rose from forty-nine percent of all exports in 1938 to $57.5 \%$ by 1950 . See Bernard Porter, The Lions' Share, A Short History of British Imperialism 1850-1983 (London: Longman, 1984), 320.

26 James Goldrick, "Carriers for the Commonwealth" in T.R. Frame, J.V.P. Goldrick and P.D. Jones, Reflections of the Royal Australian Navy (Kenthurst: Kangaroo Press, 1991).

27 Peter Morton, Fire Across the Desert, Woomera and the Anglo-Australian Joint Project 1946-1980 (Canberra: Australian Government Publishing Service, 1989).

28 Donald McIntyre, Background to the ANZUS Pact, Policy-making, Strategy and Diplomacy 1945-55 (New York: St Martin's Press, 1995), 46-49.

29 Chris Waters, The Empire Fractures, Anglo-Australian Conflict in the 1940s (Melbourne, Australian Scholarly Publishing, 1995), 26.

30 National Archives of Australia (NAA): CRS A6706/I Menzies to Attlee, 17 January 1950. See also Richard Aldrich, G.C.H.Q., The Uncensored Story of Britain's Most Secret Intelligence Agency (London: Harper Press, 2011), ch. 5. 
The Korean War led to further fundamental change in Commonwealth cooperation, which altered the trajectory of many of the immediate post-war influences. Many of the results initially appeared to further enhance co-operation with Australia's first reaction to the conflict being a decision to despatch Royal Australian Air Force (RAAF) aircraft to reinforce the British counter-insurgency campaign in Malaya. ${ }^{31}$ By 1951 a unique Commonwealth Division had been formed in Korea with British and Canadian brigades and units from Australia and New Zealand. At sea Commonwealth operations and co-operation were extensive, with 76 ships involved including $32 \mathrm{RN}, 9$ RAN, 8 RCN and 6 RNZN. Britain provided the Royal Fleet Auxiliaries (RFA) that provided much common support and sustainment and there was mature inter-action on a basis of complete equality. ${ }^{32}$ Britain normally provided one aircraft carrier but from October 1951 - January 1952 that burden was shared by HMAS Sydney, which flew 2,366 sorties, but the extent of inter-dependence was demonstrated by the fact the Commander(Air), the Operations Officer, Flight Deck Officer, Commander Air Group and two of three squadron Commanding Officers were all RN officers on loan. ${ }^{33}$

However the operational intimacy and resulting effectiveness that was now virtually instinctive had to be balanced against strategic developments which tended to undermine them. The most significant of these was the rapid emergence of China as a great power, capable of projecting military forces beyond its borders. While this capability had been contained in Korea it was not defeated, something that also had to be applied to the new Chinese air force, based on considerable mutual assistance from Russia and equipped with Russian produced MiG-15 jets. In what could be seen as an analogy of the fleet unit, half a century on, China moved in three years from possessing no air force to being the world's fourth largest airpower. The impact of these developments was to dissolve the Commonwealth consensus of focusing on a Soviet and European-centred general-war threat. Chinese communism now emerged as a much more substantial and immediate threat to South Asia. Instead of a secondary threat from sporadic guerrilla activity in Malaya, there was now an apprehension of waves of Chinese 'volunteers' supported by first rate airpower; and Korea had demonstrated that in such a scenario it was unlikely atomic weapons could be used to counter such an attack. Coupled with this was the very suddenness with which the Russian supported Chinese capability had developed, which tended to move planners in the direction of 'worst case' scenarios. As Sir Arthur Tange, then the Australian UnderSecretary of External Affairs and later Secretary of Defence, put it, the events of 195051 "set the alarm bells ringing and waken ghosts of 1941-42." 34 The Chinese

31 Peter Edwards, Crises and Commitments, The Politics and Diplomacy of Australia's Involvement in Southeast Asian Conflicts 1948-1965 (Sydney: Allen \& Unwin, 1992), 97.

32 UK National Archives, Kew, ADM 234/385, British Commonwealth Naval Operations, Korea, 1950-53 and Stephen Prince, "The Contribution of the Royal Navy to the United Nations Forces during the Korean War,” Journal of Strategic Studies, 17: 2 (1994).

33 Alistair Cooper, "1945-1954: The Korean War Era" in David Stevens (ed.) The Royal Australian Navy (Melbourne: Oxford University Press, 2001), 177.

34 Author's interview with Sir Arthur Tange, Canberra, 16 April 1996. 
volunteers and the Mig-15 now took the place of Japanese Imperial infantry and the Zero fighter. In this new situation Australia and New Zealand became increasingly concerned about the size, scope and quality of forces the UK would be able to deploy to the Middle East or Malaya theatres in a general war. Though Britain was re-arming, the increased apprehension of war also applied to Europe, where the threat was now perceived to be more explicitly military. As NATO converted from December 1950 onwards from a treaty into a genuine organisation it was necessary for the UK to convert its occupation forces into operational units in order to encourage US reinforcements and then balance moves to West German re-armament, resulting in very explicit treaty commitments by 1954 . This pattern, together with the limits of British industry demonstrated during the re-armament, qualified likely deployment outside Europe and so led to more conditional support from Australia and New Zealand for despatching reinforcements to the Middle East or Malaya. Though planning continued both dominions held back from explicit commitments. ${ }^{35}$

Simultaneously relations with America were improving, with Australians impressed with the USA's decisive reaction to aggression in Korea and America also impressed by Australia's early commitment of forces on land, sea and air. This atmosphere, and operations together, inevitably led to increased information exchange. Also the USA now prioritised achieving an early Japanese Peace Treaty, in order to cement Japan into the anti-communist camp. One result was the Australia, New Zealand, and United States (ANZUS) Pact of 1951 in order to ease the process. The Pact did not include the UK and Australia now saw closer direct relations with American as both a higher priority and more achievable. When the full scope of these relations did not emerge, Australia assessed that part of the reason would be US ambiguity arising from the Anglo-Australian links, and so chose to further prioritise the US over Britain. While there was an element of truth to this there was also a factor of the basic power imbalance. When America's Joint Chiefs of Staff had inserted a reference to Commonwealth Defence into the preamble to the ANZUS Treaty it had not been a UK inspired spoiler but an American means to try and limit expectations of a close relationship. ${ }^{36}$

Divergent forces were also increasingly present in the underlying economics and procurement. As a result of the Korean War and US re-armament Australia, in common with the other Dominions, received a considerable influx of US dollars. Generally this resulted from increased demand for primary products, with the world wool price rising 400 percent 1948-1951, though in Australia's case it was also increased by US loans on favourable terms. ${ }^{37}$ With dollars and information both flowing Australia was freer to chose new equipment patterns and commenced with a decision for domestic production of the US F-86 Sabre jet as a Mig-15 matching

35 Robert O'Neill, Australia in the Korean War 1950-53, Volume I: Strategy and Diplomacy (Canberra: Australian War Memorial \& Australian Government Publishing Service, 1981), ch. 23. McGibbon, New Zealand and the Korean War, Volume I, ch. 25.

37 Lee, The Search for Security, 140. 
fighter, superseding plans to produce British pattern aircraft, despite the fact Sabres were three times the unit costs and required a high dollar input, $\$ 7.5$ million initially. ${ }^{38}$ This dramatically reduced the scope for Australian fighter aircraft, and therefore overall forces, to deploy intimately with the UK, as opposed to the US, in any demanding scenario. The UK could now not provide a common support structure and Australia had little capacity to deploy one. Though the explicit and public preference for US compatible equipment would only come in 1957 this decision marked the real turn by Australia from Britain to the US as the necessary ally in any high intensity conflict. ${ }^{39}$ Australia also clearly hoped that their country could also become a centre for US offshore procurement, where America would pay in dollars for equipment to be exported to US allies. This was a further example, similar to information, where Australia believed it could achieve a relationship with America analogous to a major NATO ally and more explicitly Canada. ${ }^{40}$ Once again Australia was disappointed with the scope of the results, but once made the decision was virtually impossible to reverse and, on balance, it was still considered the best option.

However it is also important to appreciate that Britain's attitude and perception was also evolving. With the Korean War Britain took up an exceptionally heavy programme of re-armament, partly to align with America and also to promote allied and NATO unity. During this process Britain became increasingly disappointed with the scale and investment the Southern Dominions were making in their defence capacity, mirror imaging Dominion concerns about Britain's ability to deploy adequate forces beyond Europe. This disappointment remained largely private, as there was no wish to alienate intimate allies, but Commonwealth re-armament was increasingly and unfavourably contrasted with re-armament in Europe. ${ }^{41}$ By 1953 UK defence expenditure had reached $12.8 \%$ compared to Australia's $4.8 \%$ and New Zealand's $3.5 \%{ }^{42}$ British officials compared accelerating orders for equipment for Europe with increasingly deferred orders from the Dominions. Implicitly Britain's emphasis moved towards allies who would be available in for what Britain believed would be the decisive theatre in what was predicted to be a short conflict. ${ }^{43}$ As usual, Norman Friedman is perceptive in his assessment that, NATO was becoming in some sense a

38 NAA, CRS, A4638/XM1, Australian Cabinet Decision, 22 February 1951. Sabres cost £A 241,000 per unit as opposed to \$A 80,000 for British pattern Hunters, RAAF Historical Branch, Item 12346, "Report on Aircraft Costs," 11 November 1952.

39 For the 1957 decision see Jeffrey Grey, A Military History of Australia (Cambridge: Cambridge University Press, 1990), 219-223.

40 RAAF Historical Branch, Item 12353, "Report on the Australian Aircraft Industry," 31 August 1953.

41 UK NA DO 35/5940, Note on Australian Defence Review, 12 March 1957.

42 New Zealand Archives, AAFD 811, 222/2/1 New Zealand Treasury Memo, 30 April 1954.

43 Many NATO orders were also underpinned by the USA's Mutual Defense Assistance Plan (MDAP). See Lord Ismay, NATO, The First Five Years 1949-1954 (Netherlands: BoschUtrecht, 1956). 
substitute for the Commonwealth. ${ }^{44}$

It was this British emphasis that reinforced a more intimate British association with Canada. Britain and Canada's mutual economic inter-dependence had been illustrated in 1946 with Canada's $\$ 1.25$ billion loan to Britain, from the only dollar based economy in the Commonwealth. The loan was one third the size of that from the USA but five times more significant in terms of relative population, though usually absent from British accounts. ${ }^{45}$ Also significant was Britain's acceptance of Canada's position with America, with Canada achieving a formal security link with America first, through its hemispheric location and pattern of sustained close co-operation since $1940{ }^{46}$ Though there were a few exceptions Britain was generally mature and mutually supportive of Canada, with the Anglo-American Burns-Templar Agreement explicitly including a separate agreement to include Canada on equal terms. ${ }^{47}$ Equally Canada was keen to nurture the relationship as, having achieved security links with the USA, Canada was keen to engage with allies that could help balance the magnitude of America. Both parties also observed Canada's requirement that close links should not be advertised as 'Commonwealth'. For Canada, security links had to be post-imperial and the Commonwealth was more an area for diplomacy that could engage with the new nations of Asia. In Korea Anglo-Canadian actions were closely co-ordinated, with the British and Canadian brigades making viable the highly visible Commonwealth Division, though Canada tried unsuccessfully to avoid that popular title. The ease with which this was achieved also facilitated the integration of another Canadian brigade into the British Army of the Rhine and a Royal Canadian Air Force (RCAF) Wing into Fighter Command. ${ }^{48}$ Co-operation also extended to attempts to restrain the US in the crisis of the Korean War following successful Chinese intervention. Though $\mathrm{Mr}$ Attlee's visit to Washington in December 1950 involved public consultation with the Commonwealth his private co-ordination with Canadian diplomacy was far more significant. ${ }^{49}$ Procurement and expenditure was also closely aligned with Canadian F86 Sabre and British Hunter production co-ordinated and Britain buying Sabres as

44 Comments by Dr Friedman in discussion at the Australian Defence Force Academy, July 2011.

45 For instance, Peter Hennessy, Never Again (London: Vintage, 1993), 61.

46 Stanley Dziuban, Military Relations Between the United States and Canada 1939-1945 (Washington: Department of the Army, 1959), particularly ch. XII.

47 National Archives of Canada (NAC) RG24 21, 247 1601.1 VI Cabinet Defence Committee Memo "Exchange of Information between the US, UK and Foreign Powers", 3 May 1950.

48 David J. Bercuson, "Canada, NATO and Rearmament, 1950-1954: Why Canada Made A Difference (But not for very long)" in John English and Norman Hillmer (eds), Making a Difference? Canada's Foreign Policy in a Changing World Order (Toronto: Lester Publishing, 1992).

49 "Extract from Canadian Cabinet Conclusions, 9 December 1950," document no. 186 in Greg Donaghy (ed.) Documents on Canadian External Relations, Volume 16, 1950 (Ottawa: Department of Foreign Affairs and Trade, 1996), 285-289. Also at http:// epe.lac-bac.gc.ca/100/206/301/faitc-aecic/history/2013-05-03/www.international.gc.ca /department/history-histoire/dcer/details-en.asp@intRefid=7206. 
Canada bought British Centurion tanks. By 1953 Canada was spending $8.3 \%$ of GDP on defence and in absolute terms it's spending was half of Britain's and four times Australia's. ${ }^{50}$ While the RN supported the RCN in an apparently similar way to the RAN over carriers and submarines this was at the centre of a much larger and more enduring strategic alignment, represented in the Canadian, British and American participation in major NATO maritime exercises such as Mainbrace in 1952 and Mariner in $1953 .^{51}$ Ironically, it would be Australia and New Zealand that would support Britain in the disastrous Suez expedition of 1956, but Canada that would then help broker the cease-fire and facilitate Britain's withdrawal, commanding the United Nations Emergency Force (UNEF), a force enabled by the troops and supplies delivered by HMCS Magnificent, an RN ship on loan to the RCN and returned six months later. Suez is often perceived to be another bench-mark end to the imperial era, if 1945 is not accepted, but for defence and naval interaction it only represented the altered situation that had already been present since 1950-51.

\section{Clearly Post-Imperial 1956-2014}

One of the most unusual post-imperial naval relationships flourished in the wake of the Suez crisis, as the Cape route became more significant. The Simonstown Agreement of 1955 and the expansion of what was now the South African Navy (SAN) are fully explored by Allan du Toit in this volume. ${ }^{52}$ For the Royal Navy the fascinating element was virtually a new Cold War motivated ally at sea, pressing for close co-operation and buying significant amounts of British-patterned equipment. The new link would last for twenty years until South Africa's domestic policies made it untenable. Other developments were the British Commonwealth Far East Strategic Reserve with the RAN and RNZN both providing ships from 1955 as the Korean commitment ran down and the development of the Royal Malayan (later Malaysian) Navy utilising assistance from the RN, RAN and RNZN. All of these navies participated in the Confrontation with Indonesia which saw both a high proportion of the RN East of Suez and ultimate success. Simultaneously the RAN was preparing for its role in Vietnam with the US $7^{\text {th }}$ Fleet and largely utilising its US pattern destroyers. ${ }^{53}$ Britain was now concerned to limit its potential liabilities outside Europe and so withdrawal was commenced and then accelerated for economic reasons, leading to

50 Directorate of History and Heritage (DHH), Ottawa, DHH 79/137 p.122; DHH 73/1223/1325, Cabinet Defence Committee Minutes, 15 January 1951; DHH 73/1223/1327, Cabinet Defence Committee Memo 22 October 1952.

51 Marc Milner, Canada's Navy, 206; Peter T. Haydon "Canada and the RN Submarine Service 1915-2000" in Martin Edmonds (ed.) 100 Years of The Trade, Royal Navy Submarines Past, Present and Future (Lancaster: Centre for Defence and International Security Studies, 2001).

52 See also Ronald Hyam and Peter Henshaw, The Lion and the Springbok, Britain and South Africa since the Boer War (Cambridge: Cambridge University Press, 2003), particularly chs. 6, 10-12.

53 Jeffrey Grey, Up Top, The Royal Australian Navy and Southeast Asian Conflicts 1955-1972 (St Leonards: Allen \& Unwin, 1998). 
another generation of new naval services in the Gulf with varying degrees of RN assistance. Britain's withdrawal from the Cape and the Mediterranean in the 1970s meant that it became a largely 'Eastlant' navy focused on the Soviet threat and cooperating closely with the RCN through the established and now more multinational NATO channels, though bilateral relations with America remained significant for both navies. ${ }^{54}$ The RN, RCN and RAN all continued personnel exchanges and training interaction still took place in areas such as Principal Warfare Officer (PWO) training, engineering and submarines, with RAN officers commanding $\mathrm{RN}$ conventional submarines into the 1980s. ${ }^{55}$

Britain's home waters focus in some ways echoed the pre-1914 situation but wider interests were still serviced by Task Group deployments which reflected both RN ambition and continuing political demand. Withdrawal from Gulf basing never quite translated to withdrawal from the Gulf and from 1980 the RN gained a 'standing commitment' there that endures until today. ${ }^{56}$ Initially known as the Armilla Patrol, a presence it has frequently shared with Australia and Canada, including the surges for both Gulf Wars and the considerable sanction enforcement and maritime security demands of recent decades. ${ }^{57}$ When virtually the whole fleet was required for the Falklands conflict of 1982 it was notable how quickly the RNZN filled the gap. Other significant combined operations have also included the NATO led former Yugoslavia operations and the Australian-commanded East Timor deployment, in addition to current counter-piracy and maritime security operations off the Horn of Africa, as well as the Gulf. ${ }^{58}$

\section{Thoughts in and on the Twenty-first Century}

For the Royal Navy the first century of Commonwealth co-operation commenced as something of a necessity, but the form it adopted and supported was imaginative enough to offer significant mutual benefits which both governments and new navies could grasp and exploit. This interaction was not without growing pains, prejudice or the temptation to self-interested judgement but overall the record is of

54 Notably the RCN-USN cooperation during the Cuban Missile Crisis of 1962. See Roger Sarty's paper in this volume.

55 For example Lieutenant-Commander M.G. Gee RAN commanding HMS Sealion, 1983-84. See also Laurence Hickey's paper in this volume.

56 Ashley Jackson, "Imperial defence in the post-imperial era" in Greg Kennedy (ed.), Imperial Defence (London; New York: Routledge, 2008).

57 See Jean M. Morin and Richard H. Gimblett, Operation Friction, The Canadian Forces in the Persian Gulf 1990-1991 (Toronto: Dundurn Press, 1997); Greg Nash and David Stevens, Australia's Navy in the Gulf, From Countenance to Catalyst, 1941-2006 (Canberra: Sea Power Centre, Australia, 2006); Iain Ballantyne, Strike from the Sea, The Royal Navy and the US Navy at War in the Middle East, 1949-2003 (Barnsley: Pen and Sword, 2004); and Richard H. Gimblett, Operation Apollo (Ottawa: Magic Light Publishing, 2004).

58 Gary E. Weir (ed.), You Cannot Surge Trust, Combined Operations of the Royal Australian Navy, Canadian Navy, Royal Navy and the United States Navy, 1991-2003 (Washington: Department of the Navy, 2013). 
remarkably positive. The test of the Second World War was vast, but Commonwealth co-operation allowed all of the services involved to demonstrate the disproportionate value of the investment that had been made in them. From that point on their operational co-operation has been fraternal and far more diverse, both between themselves and with others. In the era of the Korean War that broad fraternity was also mutually confirmed in at the levels of policy and strategy. This evolution provided much of the experience that Britain and the RN have required to contribute positively to wider and later partnerships at sea, with much NATO interaction being implicitly modelled on the Commonwealth. For all navies and nations with a common interest in freedom of access to, and legitimate trade from the sea, such partnership is both a requirement and a distinct advantage. The Commonwealth record, and now its evolution beyond, demonstrates that the key attributes of understanding, respect and ultimately trust can yield results which determine history. 